Check for updates

New York

Cite this as: BMJ 2020;370:m2989 http://dx.doi.org/10.1136/bmj.m2989 Published: 24 July 2020

\section{Covid-19: Trump shifts tone by endorsing masks and admitting US situation will worsen}

\author{
Janice Hopkins Tanne
}

President Donald Trump signalled a shift in tone this week by admitting that the US covid-19 epidemic "would unfortunately get worse before it gets better.”

In his first televised press briefing since April on Tuesday 21 July, the president, reading from a prepared statement, also reversed his previous position and encouraged Americans to wear masks. He boasted about his successful handling of the pandemic, the provision of supplies to health workers, the "tremendous amount of testing," and low death rates, although on a per capita basis other nations are doing far better. He repeated his claim that the virus would eventually disappear.

At a second briefing on 22 July, Trump again encouraged Americans to wear masks. He did not wear one himself, although at both briefings he pulled a mask out of his pocket and said that he would wear it when he could not maintain physical distancing. He encouraged young people to avoid crowded bars.

No public health or medical experts were present at either briefing. Anthony Fauci, director of the National Institute of Allergy and Infectious Diseases, a frequent speaker at previous briefings, said that he had not been invited to attend. Trump said that Deborah Birx, the coronavirus response coordinator for the White House Coronavirus Task Force was "just outside" the briefing area. The president said that he consulted with experts and could present the information to journalists in an efficient way.

The president has apparently resumed the press briefings, which are broadcast nationally, to make up for his difficulty holding the political rallies he enjoys. The rally in Tulsa, Oklahoma, on 21 June proved a disappointment when it was sparsely attended.

As of 23 July, the US had nearly four million cases of covid-19 and over 143 ooo deaths, the highest numbers in the world. ${ }^{1}$ Trump's approval rating for his handling of covid-19 has fallen to $38 \%$, according to the Washington Post-ABC News poll. ${ }^{2}$

Trump said that the nation was doing very well in fighting what he called "the China virus" or "the China plague" and would soon extinguish the "embers" or even "fires" of the epidemic in southern and western states, while acknowledging that Florida was in a tough situation. Florida has reported more than 150000 cases in the past two weeks. He said that progress towards a vaccine would be available "a lot sooner than anyone thought possible.”

The president asserted that schools would reopen this fall " $100 \%$. ." Both parents and teachers have expressed worries about this. The teachers' association in Florida has sued to prevent reopening of schools. The president said yesterday, without citing evidence, that children were seldom infected with the virus, quickly recovered if infected, and did not transmit the virus.

At neither press briefing did the president present a national plan for the US to deal with the pandemic. Thomas Frieden, former director of the Centers for Disease Control and Prevention, told the New York Times, "We have a real vacuum of leadership at the national level." 3

Covid-19 dashboard by the Center for Systems Science and Engineering (CSSE) at Johns Hopkins University (IHU) https://gisanddata.maps.arcgis.com/apps/opsdashboard/index.html\#/bda7594740fd40299423467b48e9ecf6

2 Clement C, Balz D. Trump faces rising disapproval and widespread distrust on coronavirus, Post-ABC poll finds. Washington Post 2020 July 17. https://www.washingtonpost.com/politics/trump-faces-rising-disapproval-and-widespread-distrust-on-coronavirus-post-abc-poll-finds/2020/07/16/04aa9db2 c79d-11ea-a99f-3bbdffb1af38_story.html

3 McNeil DG. Former chief of health agency urges states to standardize data. New York Times 2020 July 22. https://www.nytimes.com/2020/07/21/health/coronavirus-data-states-cdc.html?searchResultPosition=1

This article is made freely available for use in accordance with BMI's website terms and conditions for the duration of the covid-19 pandemic or until otherwise determined by BMJ. You may use, download and print the article for any lawful, non-commercial purpose (including text and data mining) provided that all copyright notices and trade marks are retained. 